\title{
6 Memory politics and archives in Sino-Japanese relations
}

\author{
Karl Gustafsson
}

\section{Introduction}

The legacy of Japanese imperialism and aggression, often referred to as the 'history problem' (see, for example, Saito, 2016; Koyama, 2018), has long been a source of tension between Japan and its East Asian neighbours. In particular, Sino-Japanese relations have been negatively affected by issues related to how the Japanese invasion of China in the 1930s and 1940s is remembered in China and Japan (Gustafsson, 2014b; Dian, 2017). For example, the Chinese government has repeatedly complained about portrayals of the war in Japanese history textbooks (Shin and Sneider, 2011) and condemned Japanese prime ministerial visits to the controversial Yasukuni Shrine, which enshrines 14 convicted Class A war criminals along with almost 2.5 million Japanese war dead (Takenaka, 2015; Cheung, 2018). At the same time, Japanese government representatives have criticized Chinese history education and war museums for being 'anti-Japanese' (Gustafsson, 2015a). In addition, during the last few years, the history issue has increasingly come to be linked with the territorial dispute over the Diaoyu/Senkaku Islands. In this context, both the Chinese and the Japanese side have made appeals for support from the international community or particular states to a much greater extent than was previously the case (Gustafsson, 2014a; Hagström, 2015; Yennie Lindgren and Lindgren, 2017). At the same time, attempts at reconciliation have at times been made (Rose, 2005; Szczepanska, 2017), and Japanese prime ministers have made numerous statements of remorse and apology (Yamazaki, 2006). Such statements, however, have often been followed by loud claims that Japan did nothing particularly heinous in the past, or at least that Japan's transgressions were no worse than those committed by other states (Lind, 2008). In China, Japanese apologies have often been seen as inadequate, while Japanese have increasingly come to believe that Japan has already apologized sufficiently or that no amount of apologies ever will suffice (Fukuoka, 2018; Gustafsson, 2019).

Archives have played a key role in reconciliation and truth commissions and in the promotion of human rights in post-conflict settings (González Quintana, 2009; Jones et al., 2013). What role have archives played in 
Sino-Japanese relations? This chapter addresses this question through an analysis of what is arguably the most notable case in which archives have affected Sino-Japanese relations: the inscription of archival documents related to the 1937 Nanjing massacre in the United Nations Educational, Scientific and Cultural Organization's (UNESCO) Memory of the World (MoW) Register. In 2014, seven Chinese archives jointly submitted a nomination for the inscription of the documents, and in 2015, the application was accepted. This chapter discusses the inscription in the context of SinoJapanese memory politics.

The next section briefly introduces the archives with which this chapter is concerned. The section that follows, which forms the main part of the chapter, discusses in some detail the uses of the archives and the role that they have played in Sino-Japanese memory politics. Finally, the concluding section discusses the Sino-Japanese case within the broader context of the potential for archives to contribute to the promotion of reconciliation and human rights. It is suggested that the case demonstrates the limitations of archives as instruments for reconciliation and human rights promotion in international settings.

\section{The archives}

In 2014, seven Chinese archives, the Central Archives of China, the Second Historical Archives of China, Liaoning Provincial Archives, Jilin Provincial Archives, Shanghai Municipal Archives, Nanjing Municipal Archives and the Memorial Hall of the Victims in Nanjing Massacre by Japanese Invaders, submitted a nomination to UNESCO for the inscription of documents related to the 1937 Nanjing massacre in the MoW Register. The nominating archives are all in possession of documents related to the Nanjing massacre.

The Nanjing massacre is a hotly debated episode in Sino-Japanese memory politics. As such, it stimulates emotional discussion at both the government and popular levels (Callahan, 2010; Schneider, 2018). While most serious historians agree that after the Japanese army captured Nanjing in December 1937 it massacred at least tens of thousands of civilians and soldiers who had surrendered, various estimates exist concerning the scale of the massacre, most notably the exact number of victims (Fogel, 2000; Yoshida, 2006). The nomination form submitted by the Chinese archives to UNESCO states:

The Japanese army carried out the massacre in Nanjing for six weeks, which inflicted an unprecedented impact on the Chinese people, especially Nanjing citizens, and brought about a traumatic memory till today. The International Military Tribunal for the Far East confirmed in its judgment that over 200,000 Chinese were killed, and over 20,000 women were raped or gang raped by Japanese army. 'These figures do 
not take into account those persons whose bodies were destroyed by burning, or by throwing them into the Yangtze River, or otherwise disposed of by Japanese'. The Nanjing War Criminals Tribunal concluded that 'at least 300,000 Chinese were killed'.

(Central Archives of China et al., 2014, p. 9)

The nomination form further states that 'the documents nominated by these institutions form a complete chain of evidence' (Central Archives of China et al., 2014, p. 10).

The nomination included three different types of material: (1) various documents produced while the massacre was taking place, including photos taken by a Japanese officer, entries in a diary written by a Chinese resident of Nanjing and film footage shot by an American missionary, (2) documents resulting from the investigations that formed the basis of the International Military Tribunal for the Far East (also known as the Tokyo Trial) and the Chinese Nationalist Government's Military Tribunal (which took place during 1945-1947) and (3) documents compiled by the People's Republic of China's (PRC) judiciary authorities between 1952 and 1956 consisting of the testimony of two Japanese war criminals (Central Archives of China et al., 2014).

Under the heading of 'Social/spiritual/community significance', the nomination form states:

These archives mean so much emotionally to the descendants of the victims of the massacre, to the citizens of the victimized city of Nanjing, and to the people of the once injured country. Today, tens of millions of Chinese and foreign people, including Japanese people, pay their visit to the Memorial Hall of the Victims in Nanjing Massacre by Japanese Invaders annually. On December 13th each year, people hold memorial services for the victims. As from 2014, the Chinese government makes December 13th a national memorial day for the whole nation to hold mourning events and convey condolences to those killed during the Nanjing Massacre.

(Central Archives of China et al., 2014, p. 10)

The Memorial Hall of the Victims in Nanjing Massacre by Japanese Invaders is one of the nominating institutions. While the memorial hall has an archival function as it houses a large collection of documents related to the massacre, it is better known as a museum which in its comprehensive exhibition focuses on the Nanjing massacre (Zhu and Zhang, 2009; Gustafsson, 2011). The memorial hall is one of the most visited museums in the world. According to an article in the China Daily, in 2014 it received eight million visitors making it the world's second most visited museum after the Chinese Palace Museum in Beijing (China Daily, 2015). 


\section{The uses of the archives and their role in Sino-Japanese memory politics}

This section explores the uses of the archives and the role they have played in Sino-Japanese memory politics. The section departs from the notion that states do not only seek security in the sense of physical survival, but also seek to secure collective memory, or the narratives that they construct about their past. They view perceived denials of these narratives as threatening and therefore seek to secure collective memory through various means, for example through the use of education and by constructing museums and monuments. They also seek to have their collective memory narratives recognized by other states and authoritative international organizations (Gustafsson, 2014a, 2014b). Against this background, the section discusses the Japanese and Chinese reactions to the inscription into the MoW Register.

Already in June 2014, after the Chinese application had been submitted, Japanese Chief Cabinet Secretary Suga Yoshihide commented that it was 'extremely regrettable' that China was 'using UNESCO for a political purpose' and that Japan had therefore protested and asked China to withdraw its application. Suga also explicated the Japanese government's official position that during the Nanjing Massacre, 'the killing of a large number of noncombatants, looting and other acts occurred', but added that 'there are numerous theories as to the actual number of victims, and the Government of Japan believes it is difficult to say with any certainty' (Suga, 2014).

In October 2015, following the inscription of the archival materials into the MoW, Japanese government representatives made several statements. Foreign Press Secretary Kawamura Yasuhisa, for example, commented:

[T] he submitted documents were based on the People's Republic of China's unilateral assertions, and the Government of Japan believes that there are obvious problems with the documents' integrity and authenticity. It is extremely regrettable that documents such as these have been inscribed on the Memory of the World Register despite continuous protests that were progressively lodged by the Government of Japan regarding its fundamental position, and such decisions pose a problem for UNESCO, as an international organization, which should be neutral and impartial.

Kawamura went on to say that Japan intended to request that the system for inscription into the MoW be reformed to prevent it from being used 'for overtly political purposes' (Kawamura, 2015). A few days later, Chief Cabinet Secretary Suga repeated the points made by Kawamura and added that 'experts have not verified whether the documents are authentic'. In addition, he mentioned that the Japanese government would look into 'possible revisions' to Japan's financial contributions to UNESCO, 'including the suspension of their payments' (Suga, 2015a). In October 2016, Suga mentioned 
that the payment had yet to be implemented and commented: 'last year various matters were decided within UNESCO without the Government's knowledge and therefore the Government would like to see that the situation is normalized before making a decision about how to respond' (Suga, 2016b). Eventually, Japan's payments for the fiscal year of 2016 were made in December 2016. At the time, Deputy Chief Cabinet Secretary Nogami Kotaro commented concerning Japan's payments for 2017 that 'the Government will make a decision taking various perspectives into comprehensive consideration' (Nogami, 2017). In other words, the Japanese government sought through financial means to pressure UNESCO to adopt the reforms it had suggested.

In November 2015, Japanese Minister of Education, Culture, Sports, Science and Technology Hase Hiroshi delivered a speech at the UNESCO headquarters in Paris, referring to UNESCO's motto that 'it is in the minds of men that the defences of peace must be constructed' and that protecting and transmitting world heritage is key to building such defences. He stressed that 'such activities in the field of culture must unite, not divide nations', 'and must be also intended for mutual understanding and solidarity among the Member States'. He called for reforms to the MoW Programme 'in order to improve governance and transparency' (Hase, 2015). Hase repeated these views in a meeting with UNESCO Director General Irina Bokova (Suga, 2015b).

Following the inscription, the issue was also discussed in the Japanese Diet. In November 2015, Inada Tomomi of the ruling Liberal Democratic Party (LDP) made a comparison between the Chinese nomination and the Japanese application for the inscription of documents related to the Siberian internment of Japanese soldiers following the end of World War II. Inada stated that unlike the Chinese nomination, the Japanese application had been made with Russian understanding and cooperation, suggesting that applications for inscription ought to be conducted in such a way. In the same session, Minister of Education, Culture, Sports, Science and Technology Hase stressed the importance of making the member states understand that UNESCO's original purpose was to deepen mutual understanding, not to cause confrontation among member states. Therefore, he argued, it was necessary to make the process of inscription more transparent and allow for states affected by or somehow related to a particular inscription to be able to access nominated materials (The 189th Diet, House of Representatives, Budget committee meeting no. 22, 10 November 2015). ${ }^{1}$ Similar statements about the importance of making the MoW Programme conform to UNESCO's original purpose were made repeatedly by Japanese government representatives at press conferences (Suga, 2016a, 2016b).

In several Diet sessions in 2016, Foreign Minister Kishida Fumio responded to questions concerning how the Japanese Ministry of Foreign Affairs was responding to the inscription. He mentioned that even though UNESCO's regulations encourage making documents registered in the MoW 


\section{Karl Gustafsson}

Programme widely accessible, it was still unclear exactly which documents had been registered. Japan, Kishida stated, sought to dispatch specialists to carefully examine the contents of the documents. However, even though the Chinese authorities had initially agreed to let the Japanese inspect the documents, they had then refused to provide them with access, citing technical problems as the reason. Kishida stated that without inspecting the documents, it is not possible to decide how to proceed (The 190th Diet, Lower House Foreign Policy Committee meeting no. 15, 18 May 2016; the 192nd Diet, Upper House Committee for diplomacy and defence, meeting no. 2, 20 October 2016).

While Japanese reactions to the inscription were very critical and took it as a reason for promoting reform of the system for inscription in order to prevent similar incidents in the future, Chinese reactions were very positive and interpreted the inscription as recognition of the official Chinese position on the Nanjing massacre. For example, the Chinese state-operated news agency Xinhua reported: 'Researchers and the public cheered as UNESCO listed Nanjing Massacre documents on Friday, saying the inscription marks an "international recognition and consensus" of records that have been distorted by the Japanese right wing' (Xinhua, 2015b). Similarly, Curator Zhu Chengshan of the Memorial Hall of the Victims in Nanjing Massacre by Japanese Invaders, the main archival institution behind the nomination, described the inscription as 'global recognition' and said that henceforth 'any act of denial will be impotent'. He described the inscription as 'a new start for research into Nanjing massacre, one of the greatest crimes ever perpetrated against humanity'. In addition, Xinhua commented: 'Historians rank Nanjing as equal with Auschwitz, which is listed on the world cultural heritage'. Jing Shenghong, a history professor at Nanjing Normal University, remarked that 'the listing has elevated national heritage to a common wealth, as a standing call to end of atrocities' (Xinhua, 2015b).

Furthermore, Chinese reactions were very critical of the Japanese protests against the inscription. For example, the Chinese Ministry of Foreign Affairs spokesperson Hua Chunying called the Nanjing massacre a 'severe crime committed by Japanese militarism' and 'a historical fact recognized by the international community'. She also remarked: 'Facts should not be denied and history not re-written' and 'urged Japan to reflect on its history, and to stop obstructing the work of UNESCO' (Xinhua, 2015a). Hua also commented that Japan had sought to 'obstruct China's application', thereby revealing its 'reluctance to face the history squarely' (Xinhua, 2015b). Similarly, Zhu Chengshan of the Memorial Hall of the Victims in Nanjing Massacre by Japanese Invaders, commented: 'Seven decades have passed since WWII, but the lessons of war have not been learned in some countries, and that is why we applied to list the documents' (Xinhua, 2015b).

These Chinese comments make it clear that the purpose of having the archival material inscribed in the MoW was to gain international recognition 
of the Nanjing massacre as it is understood in China. Elevating the Chinese national memory of the massacre to global memory is thus a way of securing this memory against what is considered denial and therefore a threat to this memory. According to the Chinese nomination form, the nominated documents 'form a complete chain of evidence' (Central Archives of China et al., 2014, p. 10). In other words, the authenticity claims made through the nomination of the archival documents are not just a matter of whether the documents themselves are authentic. Instead, the claim made is that inscription recognizes that the official Chinese account of the events that followed after the Japanese army entered Nanjing in December 1937 is itself indisputable. A detailed version of this account is presented in the museum exhibition at the Memorial Hall of the Victims in Nanjing Massacre by Japanese Invaders, one of the nominating institutions. The memorial hall functions both as an archive and as a museum and designated patriotic education site that houses not only documents and artefacts but also objects that have been created for the sole purpose of being exhibited such as statues and paintings. As a patriotic education site, the memorial hall's museum exhibition interprets the episode in terms of lessons for the present and future meant to make Chinese people support the Chinese Communist Party and its policies and to 'realize the Chinese dream'. It is thus difficult to separate the archive from Chinese collective memory and national identity. Scholars have highlighted that a positive Chinese national identity is often constructed in contradistinction to a negatively depicted Japan and that war memory plays a key role in such narratives (Suzuki, 2007; Gustafsson, 2016).

Meanwhile, in the Japanese Diet, the issue continued to be discussed. In May 2017, Shimokawa Makita of the Japanese Ministry of Foreign Affairs answered questions about how the ministry was dealing with the issue. He confirmed that Japan's request for disclosure of and access to the documents had still not been approved and that it had therefore not yet been revealed exactly what documents had been registered. He then repeated that the ministry was working hard to ensure that the MoW Programme would promote UNESCO's original purpose. He also mentioned that as part of the work to improve the MoW system for registration, UNESCO had appointed a group of specialists. This group had recently presented a progress report that suggested that applications should be posted on UNESCO's website to make it possible to provide comments and objections. In addition, the report also suggested that in the case of items that might provoke opposition, dialogues would be held between the concerned parties (The 193rd Diet, Lower House Foreign Affairs Committee meeting no. 14, 12 May 2017). In late October 2017, Chief Cabinet Secretary Suga stated that the UNESCO Executive Board had adopted a resolution calling 'on all persons at UNESCO to abide by the principles of dialogue, mutual understanding and respect and to avoid further political tensions concerning the MoW Programme', describing the resolution as being of 'tremendous significance' (Suga, 2017). 


\section{Karl Gustafsson}

At the time this chapter is being written, a working group is examining what the most appropriate legal framework for the MoW Programme and its nomination and inscription process might look like. This is done 'with a view to increasing the transparency of the nomination process in general and suggest possible solutions for the handling of contested nominations' (UNESCO, 2019, p. 5). In other words, even though the Japanese government was unsuccessful in reversing the inscription, it seems that it has been quite successful in gaining support within UNESCO for its suggested reforms (see also Nakano, 2018).

\section{Conclusion}

This chapter has discussed the inscription of Chinese documents related to the Nanjing massacre nominated by a group of Chinese archives into UNESCO's MoW Register. The chapter has highlighted Chinese as well as Japanese reactions to the inscription. It has been shown that in China the inscription was understood as recognition of and a way of securing the official Chinese narrative about the massacre. Unable to reverse the inscription, the Japanese government focused on reforming the system for MoW inscription in order to prevent the unilateral inscription of other documents related to wartime Japanese aggression by China or other states.

Through the analysis of this case, the chapter has highlighted some of the difficulties related to archives as instruments for reconciliation in international as opposed to national settings. For example, when an archive is not just an archive but is located in a museum that promotes a particular narrative about an episode, the recognition of archival materials might lend credibility to that narrative. At the same time, the opposite might also be the case: the archive's credibility could be attacked due to its association with a particular narrative. This suggests that archives that only house documents without promoting a controversial narrative and leave the interpretation of the documents to historians are more likely to promote human rights and reconciliation in international settings.

More generally, can archives still facilitate international reconciliation? What is required for them to do so? Global recognition of a particular collective memory narrative, for example through inscription in UNESCO's MoW, might function as a way of shaming or pressuring former perpetrators into adopting a more penitent stance (cf. Gustafsson, 2015b). However, such unilateral approaches may backfire, especially when the targeted state is relatively powerful. In addition, it could also raise questions concerning why some states are targeted and not others.

In order for archives to contribute to international reconciliation, it might be a necessary precondition that initiatives seeking to gain recognition for the archives are advanced bilaterally, rather than unilaterally. Bilateral agreement concerning the status of the archives and the veracity and integrity of documents might be necessary. Any initiatives by UN bodies granting 
international recognition to particular archives probably need to involve an evaluation of the veracity and integrity of documents by professional historians from both countries. Of course, the problem with such a bilateral approach is that former perpetrators might be reluctant to agree to such initiatives. Perhaps these problems can be overcome if archives in several countries agree to nominate documents related to several sensitive historical episodes at the same time. Such an approach might make it possible to avoid a situation where one state is viewed only as a perpetrator and other states are seen only as victims. Instead, it might be possible for states in the present to jointly acknowledge their different roles in and at the same time condemn past aggression and repression.

\section{Note}

1 The full Diet transcripts referred to are available in the Gikai kaigiroku (Diet proceedings) database. Available at http://kokkai.ndl.go.jp. All Diet statements have been translated by the author.

\section{Bibliography}

Callahan, William. 2010, China: The Pessoptimist Nation. Oxford: Oxford University Press.

Central Archives of China, the Second Historical Archives of China, Liaoning Provincial Archives, Jilin Provincial Archives, Shanghai Municipal Archives, Nanjing Municipal Archives and The Memorial Hall of the Victims in Nanjing Massacre by Japanese Invaders. 2014, Nomination Form, International Memory of the World Register: Documents of Nanjing Massacre. Available at www.unesco.org/ new/fileadmin/MULTIMEDIA/HQ/CI/CI/pdf/mow/nomination_forms/china_ nanjing_en.pdf, accessed 28 January 2019.

Cheung, Mong. 2018, Political Survival and Yasukuni in Japan's Relations with China. London: Routledge.

China Daily. 2015, "Nanjing Massacre Memorial Sees Record Visitors on TombSweeping Day," China Daily, 7 April. Available at www.chinadaily.com.cn/ regional/2015-04/07/content_20016034.htm, accessed 23 May 2019.

Dian, Matteo. 2017, Contested Memories in Chinese and Japanese Foreign Policy. Cambridge, MA: Chandos Publishing.

Fogel, Joshua A., ed. 2000, The Nanjing Massacre in History and Historiography. Berkeley, CA: University of California Press.

Fukuoka, Kazuya. 2018, "Japanese History Textbook Controversy at a Crossroads? Joint History Research, Politicization of Textbook Adoption Process, and Apology Fatigue in Japan," Global Change, Peace and Security, vol. 30, no. 3, pp. 313-334.

Global Times. 2015, China to Set Up Database for Nanjing Massacre Files After UNESCO Listing, 11 October. Available at www.globaltimes.cn/content/946462. shtml, accessed 30 January 2019.

González Quintana, Antonio. 2009, Archival Policies in the Protection of Human Rights. Paris: International Council on Archives. 


\section{Karl Gustafsson}

Gustafsson, Karl. 2011, Narratives and Bilateral Relations: Rethinking the 'History Issue' in Sino-Japanese Relations, Doctoral dissertation, Stockholm: Stockholm University, Department of Political Science.

_ 2014a, "Has China's Discursive Power Increased? The 'Power of the Past' in Sino-Japanese Relations," Asian Perspective, vol. 38, no. 3, pp. 411-433.

- 2014b, "Collective Memory and Ontological Security in Sino-Japanese Relations," Asian Studies Review, vol. 38, no. 1, pp. 71-86.

- 2015a, "Identity and Recognition: Remembering and Forgetting the PostWar in Sino-Japanese Relations," The Pacific Review, vol. 28, no. 1, pp. 117-138.

- 2015b, "How to Make Former Aggressors Repent Through Shaming and Praising: The Case of Sino-Japanese Relations," Global Affairs, vol. 1, no. 3, pp. 315-324.

- 2016, "Routinised Recognition and Anxiety: Understanding the Deterioration in Sino-Japanese Relations," Review of International Studies, vol. 42, no. 4, pp. 613-633.

- 2020, "Temporal Othering, De-Securitisation and Apologies: Understanding Japanese Security Policy Change," Journal of International Relations and Development, vol. 23, no. 3, pp. 511-534.

Hagström, Linus. 2015, "The Sino-Japanese Battle for Soft Power: Pitfalls and Promises," Global Affairs, vol. 1, no. 2, pp. 129-137.

Hase, Hiroshi. 2015, 38th Session of the General Conference of UNESCO: Speech by the Head of the Japanese Delegation, 5 November. Available at www.unesco. emb-japan.go.jp/pdf/SpeechHase_Eng38GC2015.pdf, accessed 31 January 2019.

Jones, Briony, Oliveira, Ingrid, and Rubli, Sandra. 2013, Archives for a Peaceful Future. Bern: Swiss Peace Foundation.

Kawamura, Yasuhisa. 2015, New Inscriptions on the UNESCO Memory of the World Register (Statement by Foreign Press Secretary Yasubisa Kawamura), 10 October. Available at: www.mofa.go.jp/press/release/press4e_000887.html, accessed 25 January 2019.

Koyama, Hitomi. 2018, On the Persistence of the Japanese History Problem. London: Routledge.

Lind, Jennifer. 2008, Sorry States: Apologies in International Politics. Ithaca: Cornell University Press.

Nakano, Ryoko. 2018, “A Failure of Global Documentary Heritage? UNESCO's 'Memory of the World' and Heritage Dissonance in East Asia," Contemporary Politics, vol. 24, no. 4, pp. 481-496.

Nogami, Kotaro. 2017, Press Conference by the Deputy Chief Cabinet Secretary (Excerpt), 13 October. Available at https://japan.kantei.go.jp/ tyoukanpress/201710/13_a.html, accessed 25 January 2019.

Rose, Caroline. 2005, Sino-Japanese Relations: Facing the Past, Looking to the Future? London: Routledge.

Saito, Hiro. 2016, The History Problem: The Politics of War Commemoration in East Asia. Honolulu: University of Hawai'i Press.

Schneider, Florian. 2018, "Mediated Massacre: Digital Nationalism and History Discourse on China's Web," Journal of Asian Studies, vol. 77, no. 2, pp. 429-452. Shin, Gi-Wook, and Sneider, Daniel C., eds. 2011, History Textbooks and the Wars in Asia. London: Routledge. 
Suga, Yoshihide. 2014, Press Conference by the Chief Cabinet Secretary (Excerpt), 11 June. Available at https://japan.kantei.go.jp/tyoukanpress/201406/11_a.html, accessed 25 January 2019.

- 2015a, Press Conference by the Chief Cabinet Secretary (Excerpt), 15 October. Available at https://japan.kantei.go.jp/tyoukanpress/201510/13_a.html, accessed 25 January 2019.

- 2015b, Press Conference by the Chief Cabinet Secretary (Excerpt), 9 November. Available at https://japan.kantei.go.jp/tyoukanpress/201511/9_a.html, accessed 25 January 2019.

- 2016a, Press Conference by the Chief Cabinet Secretary (Excerpt), 3 June. Available at https://japan.kantei.go.jp/tyoukanpress/201606/3_p.html, accessed 25 January 2019.

- 2016b, Press Conference by the Chief Cabinet Secretary (Excerpt), 14 October. Available at https://japan.kantei.go.jp/tyoukanpress/201610/14_p.html, accessed 25 January 2019.

- 2017, Press Conference by the Chief Cabinet Secretary (Excerpt), 27 October. Available at https://japan.kantei.go.jp/tyoukanpress/201710/27_a.html, accessed 25 January 2019.

Suzuki, Shogo. 2007, “The Importance of 'Othering' in China's National Identity: Sino-Japanese Relations as a Stage of Identity Conflicts," The Pacific Review, vol. 20, no. 1 , pp. 23-47.

Szczepanska, Kamila. 2017, “Towards a 'Common' View of Difficult Past? The Representation of Atomic Bombings in Trilateral Teaching Materials," Journal of Peace Education, vol. 14, no. 1, pp. 114-129.

Takenaka, Akiko. 2015, Yasukuni Shrine: History, Memory and Japan's Unending Postwar. Honolulu: University of Hawai'i Press.

UNESCO. 2019, Terms of Reference: Open-Ended Working Group (OEWG) on the Examination of the Most Appropriate Legal Framework for the Memory of the World (MoW) Programme. Paris: UNESCO. Available at https://en.unesco.org/ sites/default/files/oewg_terms_of_reference.pdf, accessed 21 February 2019.

Xinhua. 2015a, "China Hails UNESCO Listing of Nanjing Massacre Files," 10 October. Available at www.china.org.cn/world/2015-10/10/content_36785003. htm, accessed 30 January 2019.

- 2015b, "UNESCO Listing of Nanjing Massacre Shows Global Consensus," 10 October. Available at www.china.org.cn/china/2015-10/10/content_36781283. htm, accessed 29 January 2019.

Yamazaki, Jane W. 2006, Japanese Apologies for World War II: A Rhetorical Study. London: Routledge.

Yennie Lindgren, Wrenn, and Lindgren, Petter Y. 2017, "Identity Politics and the East China Sea: China as Japan's 'Other'," Asian Politics and Policy, vol. 9, no. 3, 2017, pp. 378-401.

Yoshida, Takashi. 2006, The Making of the 'Rape of Nanking': History and Memory in Japan, China, and the United States. Oxford: Oxford University Press.

Zhu, Chengshan, and Zhang, Qingbo. 2008, Qinhua rijun Nanjing datusha yunan tongbao jinianguan chenzhan tuji [Collected Images of the Exhibition of the Memorial Hall of the Victims in the Nanjing Massacre by Japanese Invaders]. Beijing: Changcheng chubanshe. 